DOI https://doi.org/10.18551/rjoas.2020-11.08

\title{
ANALYSIS OF THE PERFORMANCE SATISFACTION OF THE HOUSING FINANCING LIQUIDITY FACILITY FINANCING: A CASE STUDY OF CENTRAL PUBLIC SERVICE AGENCY FOR HOUSING FINANCING FUND MANAGEMENT
}

\author{
Adhityo Bambang ${ }^{*}$, Simanjuntak Megawati, Yuliati Lilik Noor \\ Bogor Agricultural Institute, Indonesia \\ *E-mail: bambangadityoipb@gmail.com
}

\begin{abstract}
The disbursement of FLPP is intended to increase access and affordability of MBR in housing finance considering the availability of principal funds for housing finance (especially KPR) at low and fixed interest rates throughout the installment period (tenor) of bank financial institutions is often limited. On the other hand, an assessment is needed regarding the satisfaction of stakeholders (consumers, banks and developers). The data collection technique used in this study was convinience sampling. The basis for determining the sample is based on the availability (self-report) of data from the Ministry of PUPR. In this study, two types of analysis were used to answer the research problem, namely descriptive analysis and partial least square analysis.
\end{abstract}

\section{KEY WORDS}

Responsiveness, physical evidence, price, satisfaction.

The National Long-Term Development Plan (RPJPN) 2005-2025 provides direction related to housing development in order to meet the needs of houses that are livable and affordable by the purchasing power of the people which are managed professionally, credibly, independently, and efficiently. In fulfilling the mandate of the RPJPN, it is stated in the strategic plan of the Deputy for Finance for 2015 - 2019, a housing finance policy to create a financing system for every Indonesian family. This has implications for the importance of generating financing from the public and the capital market to provide longterm low-cost funds for housing finance.

Currently, various housing finance policies have been developed to encourage the improvement of the fulfillment of low-income communities (MBR) for livable houses, including the interest rate subsidy policy and down payment subsidies and the Housing Financing Liquidity Facility (FLPP). FLPP is housing financing assistance through the provision of lowcost long-term funds originating from the State Budget or other long-term sources of funds mixed with funds from housing finance credit issuing banks using the mixed financing method.

In the case of FLPP disbursement, the public applies for credit for housing finance to the executing bank by meeting the requirements and procedures that have been set. Next, the Housing Financing Fund Management Center through the executing bank checks the debtors who will support FLPP support. After leveraging is carried out by the Implementing Bank, the disbursement of FLPP funds can be adjusted or reimbursed by the executing bank according to the predetermined portion.

It is hoped that FLPP disbursement of credit interest rates for housing finance for MBR can be low and fixed (fixed rate) throughout the life of the loan so that credit becomes more affordable. Providing financing using the FLPP pattern is a revolving fund financing scheme, so that at a certain time there will be accumulation of funds. Thus, the allocation of housing finance assistance from government funds can, especially, especially when housing savings are institutionalized and work effectively, by other parties, to facilitate the fulfillment of housing needs for low-income families. The FLPP policy is an innovative form of housing finance assistance for MBR that is different from the previous housing subsidy policy. The previous subsidy policy was to pay the fluctuating difference in credit interest for housing finance, so that it did not pay. In addition, in the previous policy, the allocation of government 
funds for subsidies that were specifically provided and provided would increase from year to year. Expenditures to pursue the target of meeting housing needs for low-income families so that it will increasingly burden the State Budget (APBN). Kusumastuti (2015) explains that home financing through the FLPP financing program is able to encourage home ownership for low-income people. the allocation of government funds for subsidies for the allocation of government funds for provision and provision will increase from year to year to pursue the target of meeting housing needs for low-income families so that it will increasingly burden the State Budget (APBN). Kusumastuti (2015) explains that home financing through the FLPP financing program is able to encourage home ownership for low-income people. the allocation of government funds for subsidies for the allocation of government funds for provision and provision will increase from year to year to pursue the target of meeting housing needs for low-income families so that it will increasingly burden the State Budget (APBN). Kusumastuti (2015) explains that home financing through the FLPP financing program is able to encourage home ownership for low-income people.

In an effort to support the performance service activities of the service aspects of the public service agency of the Ministry of Public Works and public housing, one effort is to be able to carry out these activities with results that can be accounted for both in terms of information such as information about the satisfaction of low-income people, party services to debtors in obtaining subsidized housing, and development of adequate housing by developers, policy input and implementation of activities as well as benefits for various interested parties. Kartiningdyah (2012) provides an overview of government performance appraisal, which assesses the assessment and evaluation of government policies.

Assessment of the performance of a good public service agency is not only seen from the results that are done, but also the process that is passed in accordance with the Standard Operation Procedures (SOP) in the PPDPP public service agency of the Ministry of Public Works and Public Housing, so that the final results can be felt satisfactory by Low Income Communities (MBR). The activities of managing aspects of the public service agency of the ministry of public works and public housing need to be supported by evaluating the benefit assessment both economically, financially and in other related aspects to meet the needs of low-income people which need to be planned and developed further.

Formulation of the problem. FLPP disbursement to increase access and affordability of MBR in housing finance considering that the principal funds for housing finance (especially $\mathrm{KPR}$ ) at low and fixed interest rates throughout the installment period (tenor) from bank financial institutions are limited. The grouping of FLPP fund disbursements from 2010 - 2019 continues to increase, while the information is presented in Figure 1.

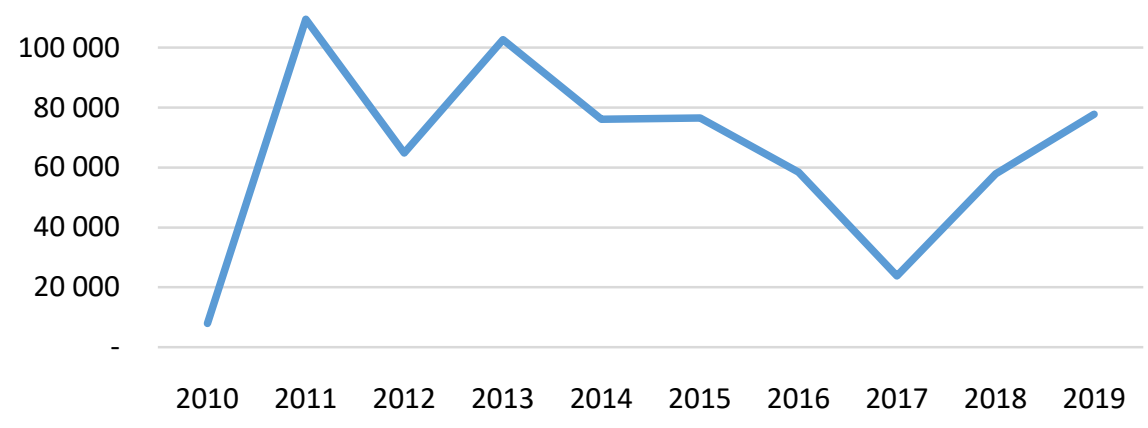

Figure 1 - Realization of FLPP

Figure 1 provides information relating to the realization of the distribution of implementation FLPP in 9 years (Realization 655.605 unit) bought to MBR. The existing policies in the PPDPP BLU program require evaluation in terms of conditions that can be maintained, reduced performance and improved to meet satisfaction with the policies of the PPDPP BLU program. Evaluation assessments need to be carried out on other stakeholders such as banks and developers. In this policy, banking is a stakeholder that is directly related 
as part of providing funds to prospective home buyers who deserve to receive FLPP funds. In addition, the developer is a stakeholder related to parties who are developers and sellers of houses to customers and become a bridge with parties. banking. Several research formulations are presented as follows:

- How is public satisfaction with housing finance?

- How is the satisfaction of banking stakeholders related to housing finance liquidity financing?

- How is the satisfaction of the developer related to housing finance liquidity financing?

\section{LITERATURE REVIEW}

Physical evidence according to Payne (2000) as a component in which there is a physical environment for service companies which then creates services so that customers can become one another. Physical evidence of the environment in which the product is made directly by consumers. Reliability is the company's ability to provide services as promised in a precise, accurate and reliable manner (Lupiyoadi 2013). Responsiveness is an ability to help and provide quickly and according to customers (Lupiyoadi 2013). Lupiyoadi (2013) guarantees syringe with the knowledge, politeness and ability of company employees to foster trust from customers to the company. Price is defined as the amount of money billed for the purchase of a product or service (Kotler and Armstrong 2012). Lamb (2001) says price is a measure that must be given by consumers (buyers) to get a product. Satisfaction is an important indicator of a business activity. Kotler (2010) satisfaction responses from customer responses to evaluation of the perceived mismatch between expectations and perceived product performance. Daryanto and Setyobudi (2014) explain that customer satisfaction with product use is based on expectations and needs that can be met from these products. Lamb (2001) says price is a measure that must be given by consumers (buyers) to get a product. Satisfaction is an important indicator of a business activity. Kotler (2010) satisfaction responses from customer responses to evaluation of the perceived mismatch between expectations and perceived product performance. Daryanto and Setyobudi (2014) explain that customer satisfaction with product use is based on expectations and needs that can be met from these products. Lamb (2001) says price is a measure that must be given by consumers (buyers) to get a product. Satisfaction is an important indicator of a business activity. Kotler (2010) satisfaction responses from customer responses to evaluation of the perceived mismatch between expectations and perceived product performance.

Izudin (2019) explains that public satisfaction with public services is closely related to responsiveness and physical evidence, this can be a basis for expressing satisfaction. Sirajuddin (2014) explains that the local government policy on basic public services in the social sector has been running according to the model, where this has resulted in four principles, namely (1) correctly answering problems, (2) proper implementation, (3) right on target, and (4) environmentally appropriate, in the public policy implementation model. Song and Meier (2018) explain that the performance of government policies is important for the government related to efficiency and increasing accountability in quality public services. Whiteley et al. (2010) explain that government performance which is illustrated by the accuracy of government decisions can have a major impact on the satisfaction of the community, this is due to the public's view that government is very important to be able to properly assess this. Wang (2010) explains that the government's ability in difficult times is an important aspect that can increase satisfaction. Salim et al (2017) satisfaction can be created when there is confidence in the performance of policy decisions, that the government has issued the appropriate policy. Wang (2010) explains that the government's ability in difficult times is an important aspect that can increase satisfaction. Salim et al (2017) satisfaction can be created when there is confidence in the performance of policy decisions, that the government has issued an appropriate policy. Wang (2010) explains that the government's ability in difficult times is an important aspect that can increase satisfaction. Salim et al (2017) satisfaction can be created when there is confidence in the performance of policy decisions, that the government has issued the appropriate policy. 


\section{METHODS OF RESEARCH}

This research was conducted in four provincy city, namely Samarinda, Palembang, Mataram and Padang. This was chosen because the area is a developing area that can still be maximized. In addition, the research was conducted from April to October 2020.This research uses quantitative and qualitative approaches. Analysis is a method based on quantitative use of numbers starting from the data approach, analysis and the appearance of the results of the study (Arikunto 2013). Qualitative research is an attempt to present the social world, and its perspectives in the world, in terms of concepts, behavior, perceptions, and problems about the human being studied (Burhan 2001). The data used in this study using primary data is data obtained only for the research conducted. In this study, primary data were obtained through interviews assisted by questionnaires. The data collection technique used in this study was convincing sampling. The research sample may be 128 respondents. The basis for determining the sample is based on several opinions including Sugiyono (2013) which states that the sample size in a good study is 30 to 500 respondents. On the other hand, Hair etal. (2010) which corroborates sampling that a good sample is under investigation if it can be 5-10 times the indicator used in the study. The criteria used in this study are shown in Table 1:

Table 1 - Sample Criteria

\begin{tabular}{ll}
\hline Respondents & Criteria \\
\hline Consumer & 1. Have done a transaction \\
Bank & 2. Still active \\
\multirow{2}{*}{ Developer } & 1. Banks sell the most MBR \\
& 2. The bank that sold the MBR at least \\
& 1. Developers sell the most MBR \\
& 2. Developers who have sold the least MBR \\
\hline
\end{tabular}

In this study using descriptive analysis. According to Sumarwan (2017), descriptive is a research method that describes the facts of an object of people, organizations, organizations and the environment. The calculation of satisfaction for stakeholder and developer banks uses the Regulation of the Minister of State Apparatus Empowerment and Bureaucratic Reform of the Republic of Indonesia 14 of 2017 while the Partial Least Square (PLS) is a regression-based method introduced for development and development models and methods for social-science approaches. prediction oriented towards Ghozali (2014).

\section{RESULTS AND DISCUSSION}

Hypothesis and significance is an analysis used to see the direction of each variable relationship and information about the strength or weakness of the relationship of each variable. This analysis aims to determine the best recommendations for the government in order to take priority to continue to improve and maintain performance. The output of hypothesis testing and significance is shown in Table 2.

Table 2 - Hypothesis Testing and Significance

\begin{tabular}{lllll}
\hline Stakeholders & Hypothesis & Original & Statistics-T & Information \\
\hline Consumer & Responsiveness -> Satisfaction & 0.214 & 2.632 & Positive and Significant \\
& Physical Evidence -> Satisfaction & 0.329 & 2.012 & Positive and Significant \\
& Price -> Satisfaction & 0.318 & 1.677 & Positive and Significant \\
\hline
\end{tabular}

The Effect of Responsiveness on Satisfaction. Responsiveness has a positive (original $=0.214)$ and significant $(T$-Stat $=2.632)$ relationship with the satisfaction of the FLPP financing policy. This condition explains that the ability to help and provide appropriate and fast services can drive satisfaction. Consumers (society) view that responsiveness is reflected in the clarity of information to obtain programs, the willingness of employees to always provide information and provide solutions. Uyoga (2018) explains that the ability of 
employees to serve is an inherent important part in any case so that this can encourage satisfaction. Ngalimanet al. (2019) explain that responsiveness is the initial part that needs to be managed to get satisfaction, this encourages employees of an organizational organization who are able to serve customers.

The Effect of Physical Evidence on Satisfaction. Physical evidence is known to have a positive (original $=0.329$ ) and significant $(T$-Stat $=2.012)$ effect on the satisfaction of the FLPP financing policy. Physical evidence related to components that are physically present and attached to the service, direct physical evidence. Wordet al. (2016) explained that evidence that physicality is an important part of being satisfied by users of a product is due to the parts that users can feel. Thusyanthy (2016) explains the physical evidence seen from the outer appearance and interior appearance is able to drive customer satisfaction.

The Effect of Price on Satisfaction. Price has a positive effect (original $=0.318$ ) and significant (original $=1.677$ ). This condition is due to the view of the public which is that the price set should still be better designed so that in the future it can reduce prices or improve quality. Ollise et al. (2018) explain that price can have a significant effect when the price is determined according to quality, this gives the idea that consumers tend to get an advantage over the product purchased. Ehsani and Ehsani (2014) explain that consumer satisfaction can be created when the price set by the producer can be supported by reciprocity in the form of products that match expectations.

Bank and Developer Satisfaction Assessment. The assessment of bank and developer satisfaction uses the approach of the Regulation for Utilization of the State Apparatus and Bureaucratic Reform of the Republic of Indonesia 14 of 2017. Based on the 4 regions it is known that they have different indexes, while the results of calculations from each region are presented as in Table 3.

Table 3 - Bank Satisfaction based on Satisfaction Index

\begin{tabular}{lllll}
\hline Indicator & Samarinda & Palembang & Mataram & Padang \\
\hline Index value & 3.08 & 3.3 & 3.23 & 3.07 \\
Score & 77 & 82.5 & 80.75 & 76.75 \\
Service Quality & B & B & B & B \\
\hline
\end{tabular}

Table 3 on having differences in service quality related to satisfaction. Banks in the Samarinda, Palembang, Mataram and Padang regions considered that the performance of the FLPP policy was considered good. The bank considers that the responsiveness of the Ministry is as expected, but in this case the response to providing information is demanded to be better so that the satisfaction of the bank increases. Alabbodi (2019) explains that responsiveness in serving is an important thing that needs to be maintained so that satisfaction remains positive for an organization. Ibrahim et al. (2016) explain that responsiveness can describe consistency and dependent attitude in serving customers. Kartikaningdyah (2012) shows that the index value of public satisfaction with policies needs to be grouped by category, so that it can provide an evaluation to the government to improve performance that needs to be improved so that future performance can increase. Saputra (2016) explains that crisis indicators are needed for policies, this is based on the things to be achieved from the policy. The increase in home ownership credit (KPR) is determined by the credit service provided by banks. It is recommended that credit services be further improved, especially those related to reliability so that various complaints can be avoided from customers and strive to fulfill their hopes and desires in satisfying customers. So that it can provide an evaluation to the government to improve performance that needs to be improved so that future performance can increase. Saputra (2016) explains that crisis indicators are needed for policies, this is based on the things to be achieved from the policy. The increase in home ownership credit (KPR) is determined by the credit service provided by banks. It is recommended that credit services be further improved, especially those related to reliability so that various complaints can be avoided from customers and strive to fulfill their hopes and desires in satisfying customers. So that it can provide an evaluation to the government to improve performance that needs to be improved so that future performance can increase. 
Saputra (2016) explains that crisis indicators are needed for policies, this is based on the things to be achieved from the policy. The increase in home ownership credit (KPR) is determined by the credit service provided by banks. It is recommended that credit services be further improved, especially those related to reliability so that various complaints can be avoided from customers and strive to fulfill their hopes and desires in satisfying customers. Saputra (2016) explains that crisis indicators are needed for policies, this is based on the things to be achieved from the policy. The increase in home ownership credit (KPR) is determined by the credit service provided by banks. It is recommended that credit services be further improved, especially those related to reliability so that various complaints can be avoided from customers and strive to fulfill their hopes and desires in satisfying customers. Saputra (2016) explains that crisis indicators are needed for policies, this is based on the things to be achieved from the policy. The increase in home ownership credit (KPR) is determined by the credit service provided by banks. It is recommended that credit services be further improved, especially those related to reliability so that various complaints can be avoided from customers and strive to fulfill their hopes and desires in satisfying customers.

This condition indicates that the policy issued is able to provide guarantees to the bank regarding the appropriate implementation, in the case that the government, through the Ministry of PUPR, is required to remain able to adhere to all regulations related to bank guarantees. Islam and Ali (2011) explain that assurance is an important part of being able to encourage satisfaction, this is because it provides an impact guarantee on a sense of certainty. Akram and Saif (2009) explain that guarantees are able to encourage satisfaction, this is related to the certainty of every offer that is given. Assessment of the satisfaction condition of the developer at the FLPP financing policy is presented in the Table4.

Table 4 - Developer Satisfaction based on the Satisfaction Index

\begin{tabular}{lllll}
\hline Indicator & Samarinda & Palembang & Mataram & Padang \\
\hline Index value & 3.08 & 3.36 & 3.4 & 3.16 \\
Score & 77 & 84 & 85 & 79 \\
Service Quality & B & B & B & B \\
\hline
\end{tabular}

Table 4 provides an illustration that developer satisfaction has a different assessment in each region. The service quality in Samarinda, Palembang, Mataram and Padang was considered good or satisfied. This is based on the ability of the performance of the responsiveness and reliability. Responsiveness is seen by the developer as very important, in this case the developer hopes that the government can continue to provide the best service with fast service and the best response. Khuong and Dai (2016) explain that a fast and appropriate response is able to encourage satisfaction, where this is due to the expectations of other parties to get the best service. Santoso and Aprianingsih (2017) explain that fast service from a waiter is able to have a big impact on satisfaction. reliability related to the ability to provide services that are appropriate and consistent and according to what has been determined. FLPP financing policies are required to be reliable in order to provide satisfaction from the developer. Experts et al. (2019) explained that reliability is able to drive satisfaction where reliability is closely related to the ability to provide a product that is suitable and fixed from time to time. Gagnon and Roh (2008) explain that satisfaction can arise when an organization can show reliability in serving other parties. Song and Meier (2018) explain that the performance of government policies is important for the government related to efficiency and increasing accountability in quality public services. FLPP financing policies are required to be reliable in order to provide satisfaction from the developer. Experts et al. (2019) explain that reliability is able to encourage satisfaction where reliability is closely related to the ability to provide a product that is suitable and fixed from time to time. Gagnon and Roh (2008) explain that satisfaction can arise when an organization can show reliability in serving other parties. Song and Meier (2018) explain that the performance of government policies is important for the government related to efficiency and increasing accountability in quality public services. FLPP financing policies are required to be reliable in order to provide satisfaction from the developer. Experts et al. (2019) explain that reliability can drive 
satisfaction where reliability is closely related to the ability to provide a product that is suitable and fixed from time to time. Gagnon and Roh (2008) explain that satisfaction can arise when an organization can show reliability in serving other parties. Song and Meier (2018) explain that the performance of government policies is important for the government related to efficiency and increasing accountability in quality public services. (2019) explain that reliability is able to encourage satisfaction where reliability is closely related to the ability to provide a product that is suitable and fixed from time to time. Gagnon and Roh (2008) explain that satisfaction can arise when an organization can show reliability in serving other parties. Song and Meier (2018) explain that the performance of government policies is important for the government related to efficiency and increasing accountability in quality public services. (2019) explain that reliability is able to encourage satisfaction where reliability is closely related to the ability to provide a product that is suitable and fixed from time to time. Gagnon and Roh (2008) explain that satisfaction can arise when an organization can show reliability in serving other parties. Song and Meier (2018) explain that the performance of government policies is important for the government related to efficiency and increasing accountability in quality public services.

\section{MANAGERIAL IMPLICATIONS}

Research is determined by managerial recommendations taking the perspective of para satisfaction stakeholders There are managerial implications such as the following:

- Consumer. Responsiveness is considered as a variable related to stakeholder satisfaction. In this case the role of responsiveness can be increased by 1) Availability of information can be increased through the Ministry of Public Works and Housing's website and applications related to housing finance 2) Conducting "exhibition" socialization by looking at the aspect of information dissemination and / or a large market so that the target to be achieved is more accurate and 3) Conduct training for Ministry employees in order to have a faster and more precise role in serving stakeholders. The impact of the implementation of these three activities is that the implementation is more precise and information related to policies can be distributed evenly to every stakeholder who needs it. 4) Coordination with local governments regarding the FLPP program so that it can be conveyed to the surrounding community. 5) Making public service advertisements related to the FLPP program in the form of mass media, SMS and social media so that information obtained by consumers is better known. The impact of the implementation of these activities is that information related to FLPP policies is getting faster, more precise and evenly distributed to stakeholders in need.

- Bank. FLPP financing policies need to take the views of the bank in order to achieve satisfaction. The concept of responsiveness to bank stakeholders is associated with efforts to manage communication and participation from both parties. Guarantee can be managed by ensuring all procedures and security can run as expected. There are several steps that need to be taken by the Ministry in order to improve bank performance and satisfaction through 1) Holding regular Focus Group Discussions on the implementation of FLPP policies and 2) Availability of integrated system development between stakeholder data with several criteria, namely monitoring evaluation of the distribution of FLPP funds and availability of units and data collection of stakeholders (developers and communities).

- Developer. The developer, as a stakeholder in implementing FLPP policies, needs to be satisfied in order to maintain the satisfaction of other stakeholders. The responsiveness of the developer is related to the ministry's ability to communicate all terms and regulations to developers related to the house building process. Reliability can be achieved if it is managed by making sure the whole process runs well. There are several activities that need to be carried out by the Ministry including 1) Creating minimum criteria and standards for the provision of public infrastructure related to housing provision through the FLPP mechanism. 2) Conduct periodic monitoring 3 ) Development of a development planning system related to the specifications of the buildings to be built and the availability of units to be built and 4) 
Hold seminars for regional developers related to FLPP fund distribution policies including the rights and obligations of developers and building standardization.

\section{CONCLUSION}

Satisfaction conditions are supported by 3 variables, namely responsiveness, physical evidence and price. The examiners note that there are 2 invalid indicators, namely DT3 and H6. The results with partial least square analysis show that responsiveness and physical evidence are able to have a positive and significant effect on the testing of FLPP financing policies.

Satisfaction of the bank by using the approach, Regulation of the Minister of State Apparatus Empowerment Number 14 of 2017 is able to provide the right reference regarding the performance of a policy. It is known that there are differences in satisfaction in each area that is the object of research but it is still in a good category. This indicates that the bank has implemented the FLPP financing policy as expected.

The satisfaction of the developer can be grouped by using the Ministerial Regulation of the Minister of State Apparatus Empowerment Number 14 of 2017. The developer considers that the implementation of the FLPP financing policy is different in each region, but is still in a good category.

In this case the government through the PUPR ministry is required to serve the satisfaction of all stakeholders. The ministry also needs to conduct a review and evaluation on the implementation of the financing policy in order to keep the targets set.

\section{SUGGESTIONS}

Satisfaction of the bank by using the approach, Regulation of the Minister of State Apparatus Empowerment Number 14 of 2017 is able to provide the right reference regarding the performance of a policy. It is known that there are differences in satisfaction in each area that is the object of research but it is still in a good category. This indicates that the bank has implemented the FLPP financing policy as expected.

The satisfaction of the developer can be grouped by using the Ministerial Regulation of the Minister of State Apparatus Empowerment Number 14 of 2017. The developer considers that the implementation of the FLPP financing policy is different in each region, but is still in a good category.

In this case the government through the PUPR ministry is required to serve the satisfaction of all stakeholders. The ministry also needs to conduct a review and evaluation on the implementation of the financing policy in order to keep the targets set.

\section{REFERENCES}

1. Akram A, Saif Ml. 2009. Service quality and its impact on customer satisfaction: an empirical evidence from the pakistani banking sector. International business \& economics research journal. 8(12): 99-104.

2. Alabboodi AS. 2019. The effect of customer satisfaction on service quality: the case of iraqi banks. International journal of applied research. 5(1): 146-152.

3. Arikunto S. 2013. Prosedur Penelitian: Suatu Pendekatan Praktik. Rineka Cipta.

4. Daryanto, Setyobudi I. 2014. Konsumen dan pelayanan prima. Gava Media.

5. Ehsani Z, Ehsani MH. 2014. Effect of quality and price on customer satisfaction and commitment in iran auto industry. International journal of service science, management and engineering. 1(5): 52-56.

6. Gagnon GB, ROh YS. 2008. The impact of customization and reliability on customer satisfaction in the u.s. Lodging industry. Journal of quality assurance in hospitality \& tourism. 8(3): 60-78

7. Hair JF, et al. 2009. Multivariate data analysis. Upper Saddle River (US): Prentice Hall.

8. Ibrahim H, Taufik M NK, Adzmir M, Saharudin H. 2016. Customer satisfaction on 
reliability and responsiveness of self service technology for retail banking services. Procedia economics and finance. 37(1): $13-20$.

9. Irwan, Adam K. 2015. Metode partial least square (pls) dan terapannya (studi kasus: analisis kepuasan pelanggan terhadap layanan pdam unit camming kab. Bone). Jurnal teknosains. 9(1): 53-68

10. Islam S, Ali MB. 2011. Measuring service quality of banks: an empirical study. Research journal of finance and accounting. 2(4): 74-86.

11. Izudin A. 2019. Kepuasan masyarakat terhadap pelayanan publik dalam mewujudkan good governance di kecamatan umbulharjo kota. J. ilmu adm. publik. 4(1): 2541-2515.

12. Kartikaningdyah E. 2012. Analisis indeks kepuasan masyarakat terhadap pelayanan publik pada bp2t kota tanjungpinang. Jurnal integrasi. 4(2): 136-147.

13. Khuong MN, Dai NQ. 2016. The factors affecting customer satisfaction and customer loyalty - a study of local taxi companies in ho chi minh city, vietnam. International journal of innovation, management and technology. 7(5): 228-223.

14. Kotler P, Amstrong G. 2012. Manajemen Pemasaran. Jakarta (ID): Ghalia.

15. Kotler P. 2010. Manajemen Pemasaran. Jakarta (ID): Salemba Empat.

16. Kusumastuti D. 2015. Kajian terhadap kebijakan pemerintah dalam pemberian subsidi di sektor perumahan. Kajian Terhadap Kebijakan Pemerintah. 4(3): 541-557.

17. Lamb JH. 2001. Pemasaran. Jakarta (ID): Salemba.

18. Lupiyoadi R. 2013. Manajemen Pemasaran Jasa Berbasis Kompetensi. Salemba Empat.

19. Ngaliman, Eka MGJ, Suharto. 2019. The effect of tangibles, responsiveness, and reliability on customer satisfaction of delivery services. Ssrg international journal of economics and management studies. 6(5): 86-92.

20. Olise MC, Ojiaku OC. 2018. Effects of product quality on customer satisfaction: a review of manufacturing company's performance in anambra state. International journal of business \& law research. 6(1): 39-47.

21. Pakuran M, Hadda H, Nagy J, Popp J. 2019. The service quality dimensions that affect customer satisfaction in the jordanian banking sector. Sustainability. 11(2019): 1-24.

22. Payne A. 2007. Service Marketing Pemasaran Jasa. Yogyakarta (ID): Graha IImu.

23. Rifai A. 2015. Partial least square structural equational modeling untuk mengukur ekspetasi penggunaan repositori Lembaga (pilot studi di uin syarif hidayatulla Jakarta). Al-maktabah. 14(1): 56-65.

24. Said M, Hamzah D, Muis M, Jusni. 2016. Mplications of establishing location, physical evidence, and customer satisfaction level of customer loyalty in ritel modern in makassar. International journal of scientific \& technology research. 5(1): $107-114$.

25. Salim M, Peng X, Almaktary S, Karmoshi S. 2017. The impact of citizen satisfaction with government performance on public trust in the government: empirical evidence from urban yemen. Open journal of business and management. 5(1): 348-365.

26. Sholiha EVN, Salamah M. 2015. Structural equation modeling-partial least square untuk pemodelan derajat kesehatan kabupaten/kota di jawa timur (studi kasus data indeks pembangunan kesehatan masyarakat jawa timur 2013). Jurnal sains dan seni its. 4(2): $2337-3520$.

27. Sirajudin IA. 2014. Implementasi kebijakan pemerintah daerah dalam pelayanan publik dasar bidang sosial di kota makassar. Jurnal administrasi publik. 4(1): 1-14.

28. Sugiyono. 2013. Metode Penelitian Pendidikan Pendekatan Kuantitatif, Kualitatif, dan R\&D. Bandung (ID): Alfabet.

29. Thusyanthy V, Senthinathan S. 2016. Customer satisfaction in terms of physical evidence and employee interaction. The iup journal of marketing management. 11(3): 7-22.

30. Uyoga D. 2018. Relationship between customer responsiveness, service performance and satisfaction among airline passengers in kenya. Conference: academy for global business advancement, 14th annual world congress.

31. Wang Z. 2010. Citizens' satisfaction with government performance in six asian-pacific giants. Japanese journal of political science. 11(1): 51-75.

32. Whiteley P, Stewart M, Sanders D, Clarke HD. 2018. Government performance and life satisfaction in contemporary britain. The journal of politics. 1(1): 1-32. 